\title{
Pridiction Of Compressive STRENGTH OF CEMENT By USING REgRESSION TECHNIQUE With PARTIAL REPLACEMENT OF HYLAM POWder In CEMENT MORTAR
}

\author{
Madhangopal.Kallutla ${ }^{1}$, G.Sreenivasulu ${ }^{2}$, C.Sashidhar ${ }^{3}$ \\ ${ }^{1}$ Assistant Professor, RGM College of Engineering (Autonomous), Nandyal \\ ${ }^{2}$ Professor, RGM College of Engineering (Autonomous), Nandyal \\ ${ }^{3}$ Professor, JNTUA, Anathapuramu
}

\begin{abstract}
This paper presents the comparison of results i.e., (compressive strength of cement) by the experimental study and Regression model to evaluate the possibility of utilizing the hylam powder as a partial replacement in cement mortar. The remarkable increase in the production of hylam and its disposal in an ecofriendly manner is increasingly becoming a matter of global concern. Hylam powder is a waste produced from hylam sheets at the time of fabrication (Cutting, Making holes and polishing process) is used as a partial replacement in cement. A total 63cement cube were casted and tested for 3,7\& 28days of seven mortar mix (i.e. 0\%, 3\%, 5\%, 7\%, 10\%, 13\% \& 15\% of Hylam powder was replaced by weight of cement). The results show that incorporation of the hylam powder yields to the increase of strength at the age (28 days) in comparison with that of a control mortar.
\end{abstract}

\section{KEYWORDS}

Hylam powder, OPC, Ennore sand, Compressive strength, and Regression Analysis

\section{INTRODUCTION}

Due to the demand of the building materials mainly in the past decades and also by increasing the growth of the population which causes chronic shortages of materials, these become a very big challenge to civil engineers to convert the industrial wastes to be useful building and construction materials. Accumulating of unmanaged wastes especially in developing countries. Recycling of wastes as a building material. The need of reducing the carbon foot print associated to cement production drove much research towards the study of by-products to be used as supplementary cementitious materials (SCMs). Many previous researches [1-15] undertaken obtained valuable results to use the industrial wastes in various forms of concrete production. For instance, the use of waste rubber, glass powder, and rice husk ash in concrete mix or cement mortar has received conscribe attention over the past years. Some researches carried out in the past used wood ash wastes as a replacement for cement in concrete mixes [1, 2]. Significant research has been directed towards the utilization of rice husk ash (RHA) as SCM [3]. S.Popovics [16], augments Abrams model, a widely used equation relating the water cement ratio of concrete to its compressive strength with the additional variables such as slump, and uses least square regression to determine equation coefficients. Using this technique improved strength prediction. 
Civil Engineering and Urban Planning: An International Journal (CiVEJ) Vol.3, No.2, June 2016

\section{Experimental Program}

\subsection{Materials}

In this study, Ordinary Portland cement grade 43, Ennore sand as a Fine aggregate and Hylam powder as partial replacement of cement was used in this test. Specific gravity of Ennore sand: 2.65 .

\subsubsection{Cement}

Ordinary Portland cement with 43 Grade has taken in this study the physical properties are given in table. 1

Table.1 Physical properties of Ordinary Portland Cement

\begin{tabular}{|c|c|c|}
\hline S.No & Properties & Results \\
\hline 1 & Specific Gravity & 3.12 \\
\hline 2 & Initial Setting Time & 55 Minutes \\
\hline 3 & Finial Setting Time & 225 Minutes \\
\hline 4 & Soundness & $2 \mathrm{~mm}$ \\
\hline 5 & Fineness & $225 \mathrm{~m}^{2} / \mathrm{kg}$ \\
\hline 6 & Consistency & $30 \%$ \\
\hline 7 & Compressive Strength & $\mathrm{N} / \mathrm{mm}^{2}$ \\
\hline A & 3 Days & 23 \\
\hline B & 7 Days & 33.12 \\
\hline C & 28 Days & 43.08 \\
\hline
\end{tabular}

\subsubsection{Ennore sand}

The standard sand shall be obtained from Ennore Tamilnadu .The specific gravity of sand 2.65 and it has in the forms of three grades which have shown in Figure1.

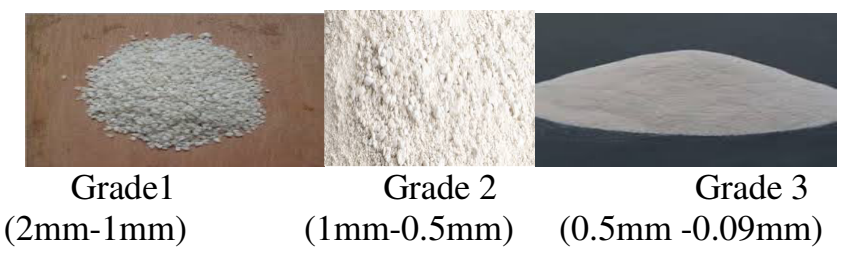

\subsubsection{Hylam}

Figure 1. Grades of Ennore Sand

Hylum is thermo setting plastic is obtained by the step-growth polymerization of resin with weaved cloth and stream will be applied in hydraulic pressure heaters $\left(200-220 \mathrm{~kg} / \mathrm{cm}^{2}\right)$ to form sheets. Phenol, Formaldehyde, Methanol \& Cardanol are the raw materials used to preparation of resin. Resin + Weaved cotton cloth $=$ Fabricated Hylum sheet. It is tough \& Versatile Engineering materials used to Electrical \& Mechanical purposes It is light in weight, good electrical insulator $\&$ resistance to water and chemical. Its applications are prefabricated wall panels, Partitions Cavity, False Ceiling, Cavity Flooring, under deck insulation etc... Specific gravity of Hylum powder was: 1.75 . 
Civil Engineering and Urban Planning: An International Journal (CiVEJ) Vol.3, No.2, June 2016

Table 2 Chemical properties of Hylum Powder

\begin{tabular}{|c|c|c|c|c|c|}
\hline Constituent & $\mathrm{SiO}_{2}$ & $\mathrm{Al}_{2} \mathrm{O}_{3}$ & $\mathrm{Fe}_{2} \mathrm{O}_{3}$ & $\mathrm{CaO}$ & $\mathrm{MgO}$ \\
\hline Compositions (\%) & 29.8 & 26 & 2.25 & 9.45 & 8.32 \\
\hline
\end{tabular}

\section{METHODS}

\subsection{Compressive strength test}

Cube specimens of size $7.06 \times 7.06 \times 7.06 \mathrm{~cm}$ of $1: 3$ proportions, using standard sand as specified by IS: 650 (1966) as Fine aggregate, tested under compression (Grade of cement indicates their compressive strength at the end of 28 days of curing).Specimen of mortar containing $0 \%, 3 \% 5 \%$, $7 \%, 10 \%, 13 \% \& 15 \%$ of Hylam powder by weight of cement were prepared. Water $=(\mathrm{P} / 4+3.0)$ percent of combined weight of cement and sand .The test was performed at the age of 3, 7, and 28 days. The strength reported was the average of three specimens for each Mixture. The strength of the cement with different percentages of Hylam powder was predicted by regression analysis by using MINITAB Software. Compressive strength had taken as response and Age of the specimen $\&$ Cement had taken as a predictor.

Thermal conductivity is the quantity of heat transmitted through a unit thickness in a direction normal to a surface of unit area due to a unit temperature gradient under steady state conditions. Conductivity coil consists of two circular disks these are made with cement mortar and attached together with no space between them. On these disks grooves are made at depth of 2 to $4 \mathrm{~mm}$ at center of disks. On these groove mica sheet is inserted by providing it with two electrodes which will act as a conducting material. Three wires are inserted inside and outside of the circular disk to record the temperature differences on the meter gauge.

\section{EXPERIMENTAL RESUlts AND Discussion}

The Figure. 2 represents the compressive strength of different percentage of Hylam powder added in cement mortar and age of cement. The optimum replacement of the Hylam power in the cement mortar is 5\%. The compressive strength decreases at 7\%, 10\%, 13\% \& 15\%.The Figure. 3 $\& 4$ represents the Predicted compressive strength from the regression equations. The regression equation was found from data as shown in table 3.

$$
\begin{aligned}
& \mathrm{Y}=-71.7+0.478 \mathrm{~A}+0.511 \mathrm{C}----------\mathrm{Eq}-1 \\
& \mathrm{R}^{2}=0.78 \\
& \mathrm{Y}=4.462+0.1119 \mathrm{C} \quad \text { (3Days) ----------- Eq-2 } \\
& \mathrm{R}^{2}=0.691 \\
& \mathrm{Y}=8.018-0.1373 \mathrm{C} \text { (7Days) ------------ Eq-3 } \\
& \mathrm{R}^{2}=0.897 \\
& Y=-4.797-0.2623 \mathrm{C} \quad \text { (28Days) -------------Eq-4 } \\
& \mathrm{R}^{2}=0.842
\end{aligned}
$$

Where $\mathrm{Y}=$ Compressive Strength of the cement cube $\left(\mathrm{N} / \mathrm{mm}^{2}\right)$

$\mathrm{A}=$ Age of the specimen i.e., (3, 7\&28days)

$\mathrm{C}=$ Cement.(Grams) 
Civil Engineering and Urban Planning: An International Journal (CiVEJ) Vol.3, No.2, June 2016

Table 3 Observed compressive strength and predicted Compressive Strength

\begin{tabular}{|c|c|c|c|c|c|}
\hline $\begin{array}{c}\text { Observed } \\
\text { Compressive } \\
\text { strength(N/m } \\
\mathrm{m}^{2} \text { ) }\end{array}$ & Age(Days) & Cement(Grams) & $\begin{array}{c}\text { Hylam } \\
\text { Powder(Grams) }\end{array}$ & Sand(Grams) & $\begin{array}{c}\text { Predicted } \\
\text { Compressive } \\
\left.\text { strength(N/mm }{ }^{2}\right)\end{array}$ \\
\hline 23.00 & 3 & 200 & 0 & 600 & 32.04 \\
\hline 33.12 & 7 & 200 & 0 & 600 & 33.95 \\
\hline 43.08 & 28 & 200 & 0 & 600 & 43.98 \\
\hline 25.40 & 3 & 194 & 6 & 600 & 28.97 \\
\hline 33.62 & 7 & 194 & 6 & 600 & 30.86 \\
\hline 45.14 & 28 & 194 & 6 & 600 & 40.91 \\
\hline 27.00 & 3 & 190 & 10 & 600 & 26.92 \\
\hline 33.96 & 7 & 190 & 10 & 600 & 28.86 \\
\hline 46.52 & 28 & 190 & 10 & 600 & 38.86 \\
\hline 23.55 & 3 & 186 & 14 & 600 & 24.88 \\
\hline 29.98 & 7 & 186 & 14 & 600 & 26.79 \\
\hline 35.61 & 28 & 186 & 14 & 600 & 36.82 \\
\hline 21.26 & 3 & 180 & 20 & 600 & 21.81 \\
\hline 27.34 & 7 & 180 & 20 & 600 & 23.72 \\
\hline 29.00 & 28 & 180 & 20 & 600 & 33.75 \\
\hline 17.34 & 3 & 174 & 26 & 600 & 18.74 \\
\hline 24.25 & 7 & 174 & 26 & 600 & 20.65 \\
\hline 26.34 & 28 & 174 & 26 & 600 & 30.68 \\
\hline 14.73 & 3 & 170 & 30 & 600 & 16.69 \\
\hline 22.37 & 7 & 170 & 30 & 600 & 18.6 \\
\hline 24.57 & 28 & 170 & 30 & 600 & 28.63 \\
\hline & & & & & \\
\hline
\end{tabular}

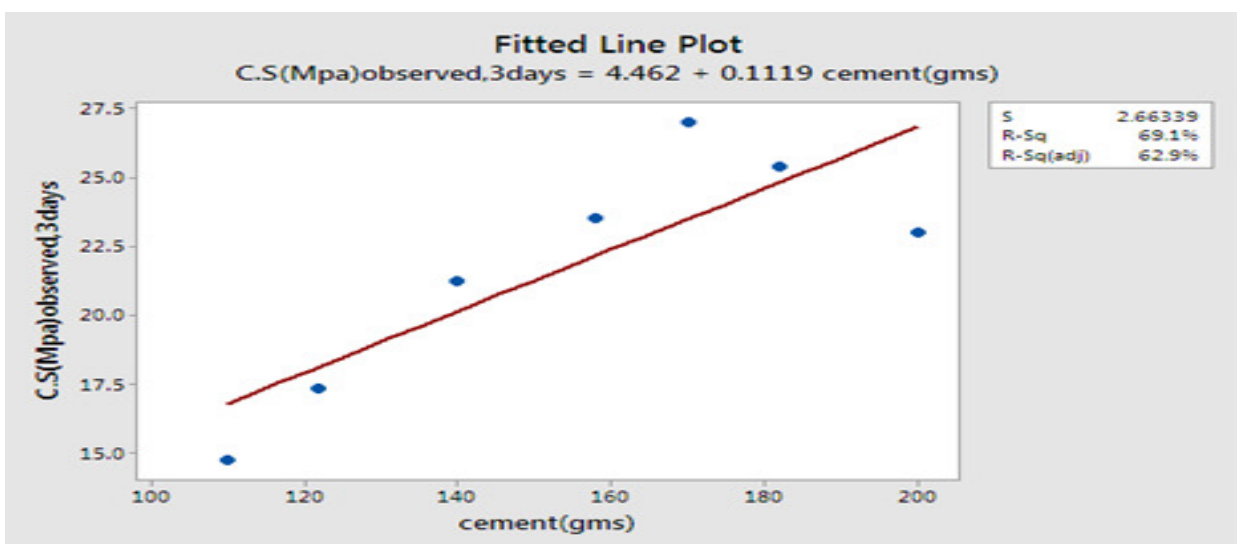

Figure1. Relation between 3days compressive strength \& cement 
Civil Engineering and Urban Planning: An International Journal (CiVEJ) Vol.3, No.2, June 2016

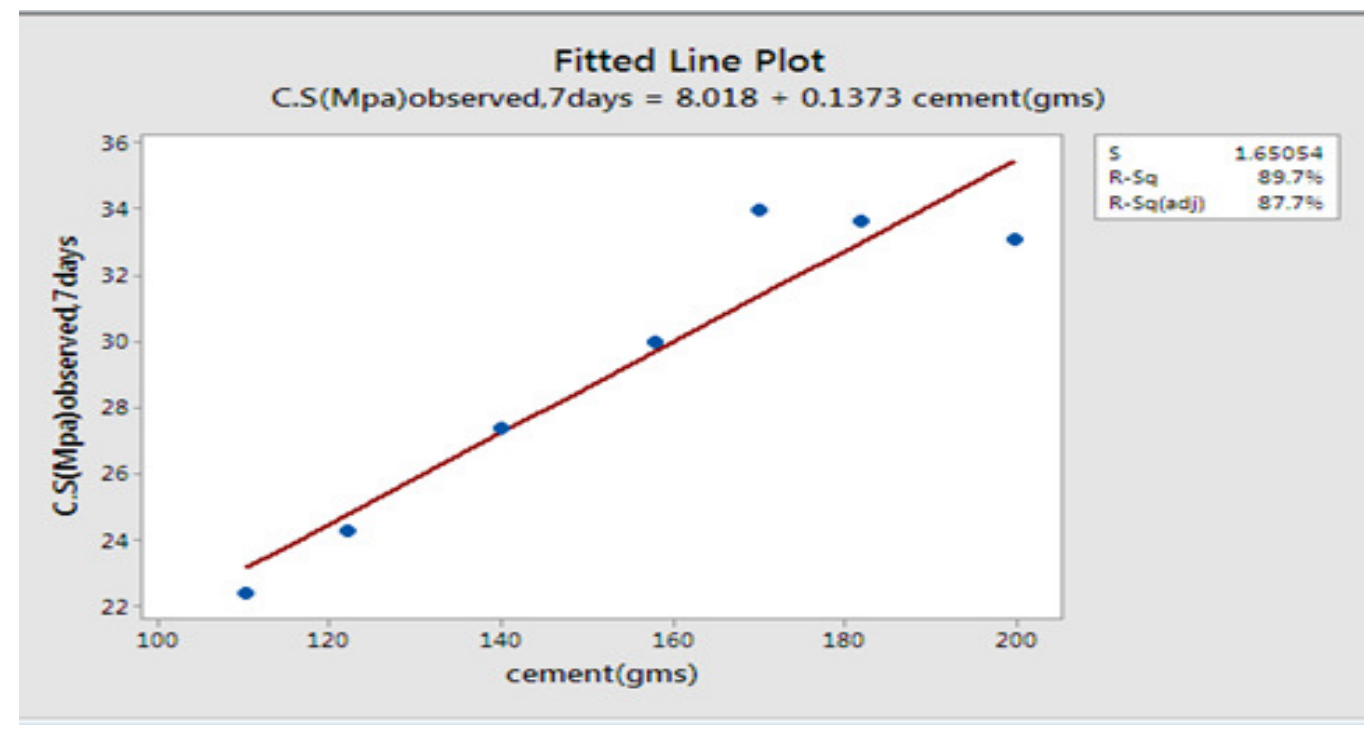

Figure2. Relation between 7days compressive strength \& cement

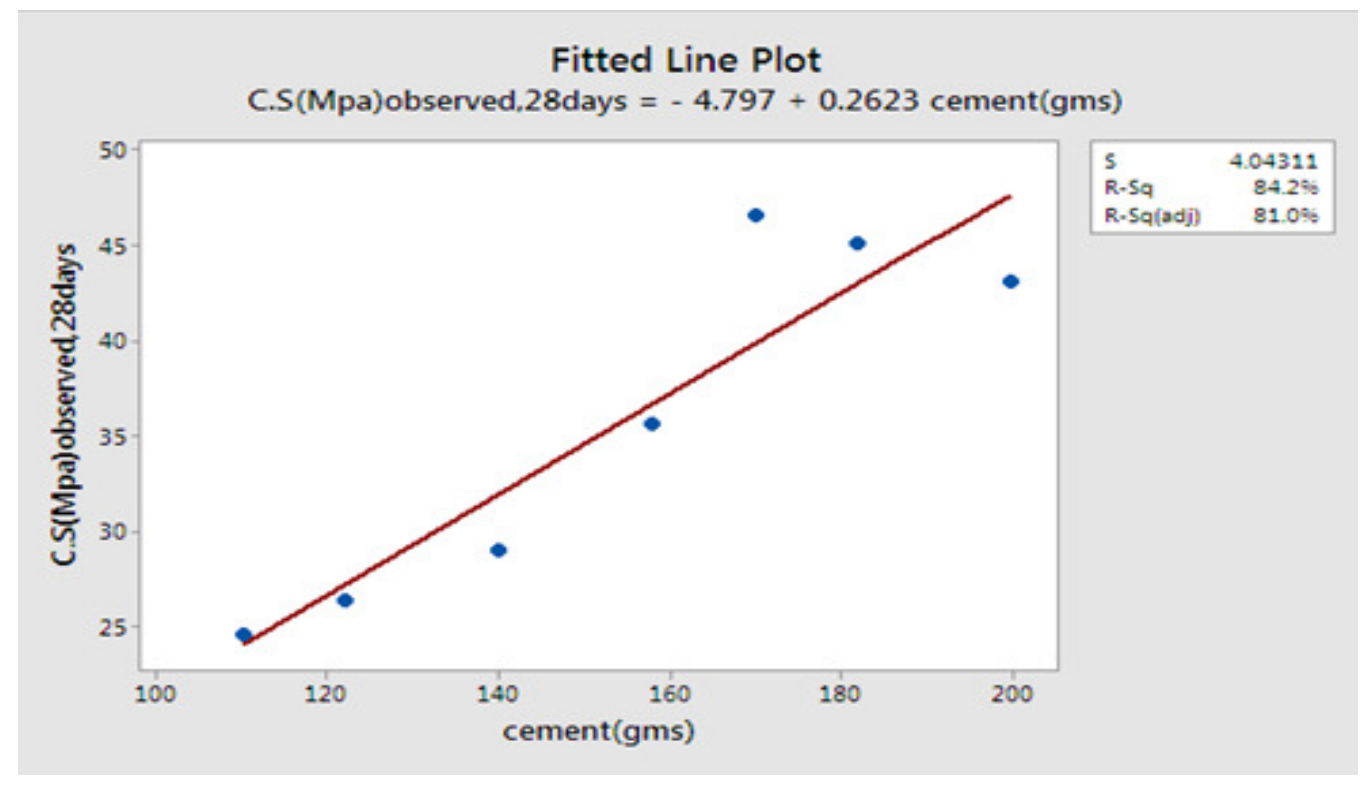

Figure3. Relation between 28days compressive strength \& cement 
Civil Engineering and Urban Planning: An International Journal (CiVEJ) Vol.3, No.2, June 2016

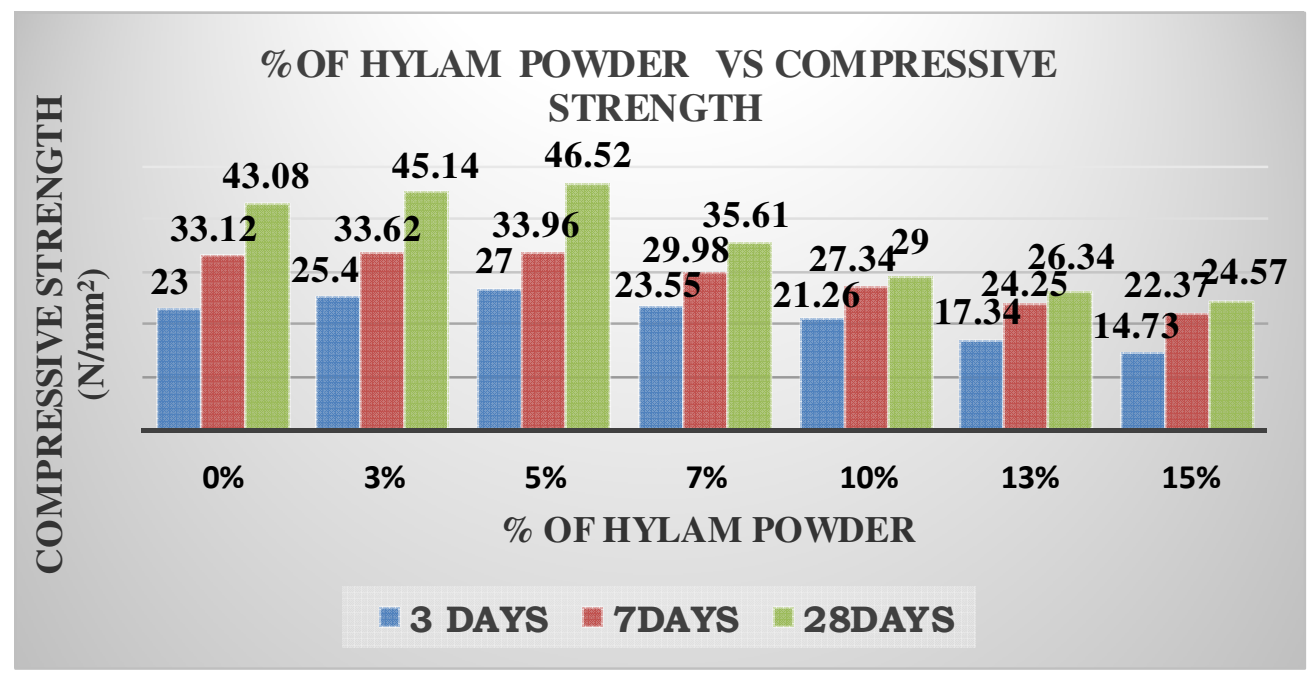

Figure 4. Observed compressive strength with different $\%$ of Hylum powder

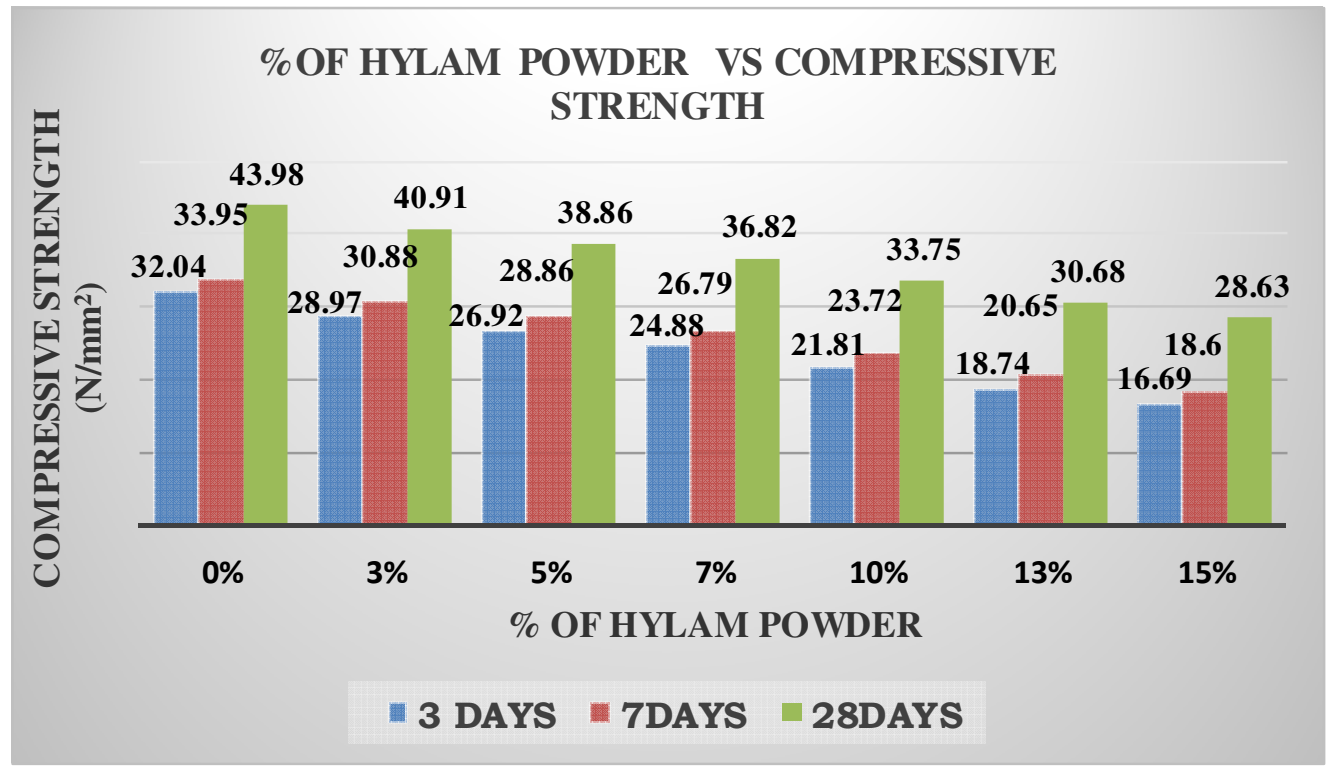

Figure5.Predicted compressive strength with different \% of Hylum powder (From Eq-1) 
Civil Engineering and Urban Planning: An International Journal (CiVEJ) Vol.3, No.2, June 2016

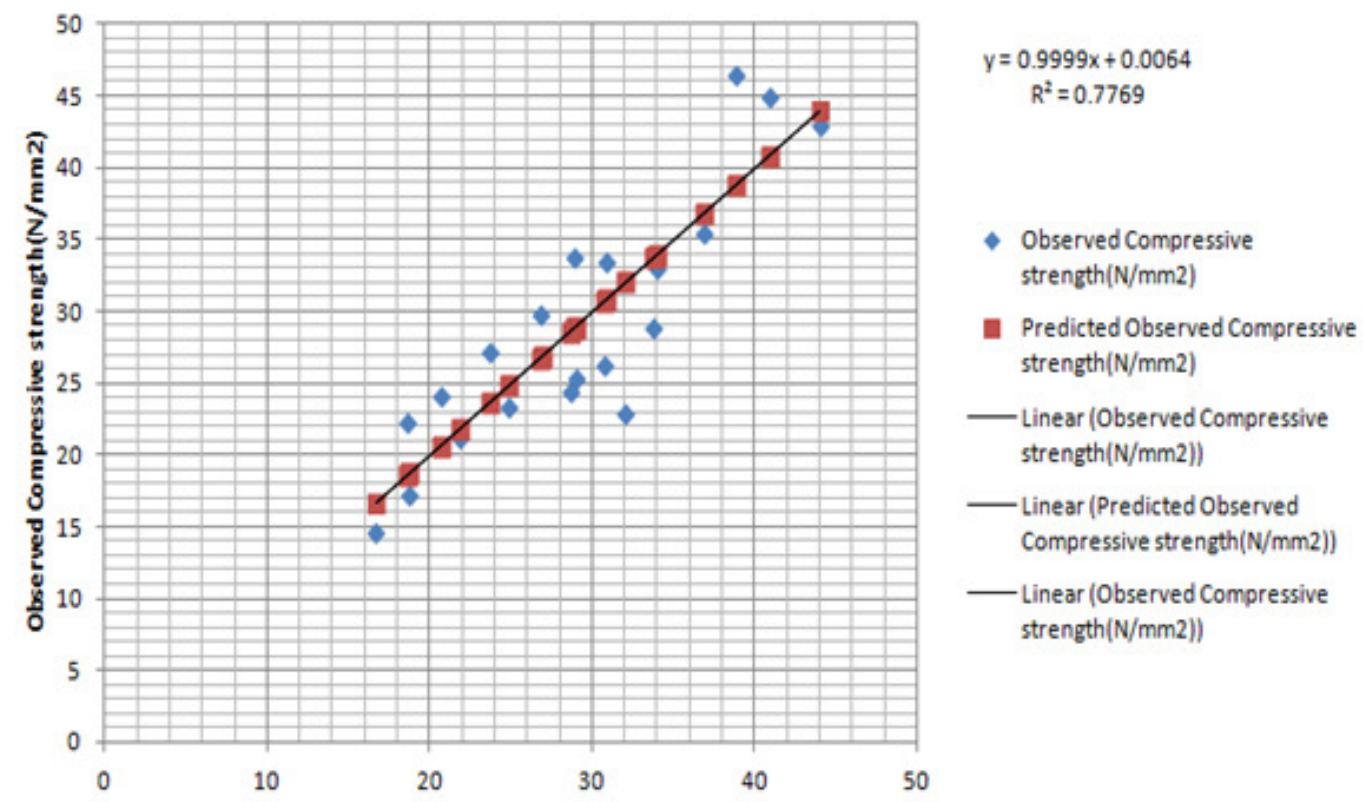

Figure6 Predicted Compressive Strength(N/mm2)

\section{CONCLUSIONS}

- The incorporation of Hylam powder yields mortars with improved strengths in comparison to that control mortar.

- When compared to the strengths of cement mortar and cement mortar with hylam powder by Partial replacement of cement exhibits more strength. When 5\% of hylam powder was replaced.

- The $\mathrm{R}^{2}$ Values for the incorporating of hylum powder were $0.691,0.89 .7 \& 0.842$ for the prediction of 3days, 7days \& 28days compressive strength of different mixes in spite of variations in the results. When the cement taken as an independent variable.

- When the Age of the specimen \& cement taken as an independent variables found that the $\mathrm{R}^{2}=0.78$.

- Conductivity of control cement mortar is $1.638 \mathrm{~W} / \mathrm{m}{ }^{0} \mathrm{C}$ and for $5 \%$ hylam powder is $1.247 \mathrm{~W} / \mathrm{m}^{0} \mathrm{C}$

\section{ACKNOWLEDGEMENTS}

The authors thank to all for the supporting to make this study possible. 
Civil Engineering and Urban Planning: An International Journal (CiVEJ) Vol.3, No.2, June 2016

\section{REFERENCES}

[1] Elinwa AU, Mahmood YA. Ash from timber waste as cement replacement material. Cement and Concrete Composites 2002; 24(2):219-22.

[2] Udoeyo FF, Dashibil PU. Sawdust ash as concrete material. ASCE, 0899-1561 2002; 14(2):173-6.

[3] Nehdi M, Duquette J, El Damatty A. Performance of rice husk ash produced using a new technology as a mineral admixture in concrete. Cement Concrete Res2003; 33:1203-10.

[4] Li G, Yu Y, Zhao Z, Li J, Li C. Properties' study of cotton stalk fiber/ gypsum composite. Cement and Concrete Research 2003; 33(1):43-6.

[5] Shao Y, Lefort T, Moras S, Rodriguez D. Studies on concrete containing ground waste glass. Cement and Concrete Research 2000; 30:91-100.

[6] Soroushian P, Plasencia J, Ravanbakhsh S. Assessment of reinforcing effect of recycled plastic and paper in concrete. ACI Materials Journal 2003; 100-M23 (3):203-7

[7] Galetakis M, Raka S. Utilization of limestone dust for artificial stone production: an experimental approach. Minerals Engineering 2004; 17:355-7.

[8] Containing Shao Y, Lefort T, Moras S, Rodriguez D. Studies on concrete ground waste glass. Cement and Concrete Research 2000; 30:91-100.

[9] Aspiras FF, Manalo JR. Utilization of textile waste cuttings as building material. Journal of Materials Processing Technology 1995;48 (1-4):379-84.

[10] Balasubramanian J, Sabumon PC, Lazar JU, Ilangovan R. Reuse of textile effluent treatment plant sludge in building materials. Journal of Materials Processing Technology 1995; 48(1-4): 379-84

[11] Ahmadi B, Al-Khaja W. Utilization of paper waste sludge in the building construction industry. Resources, Conservation and Recycling 2001; 32(2):105-13.

[12] Rossella M. Ferraro, Antonio Nanni Effect of off-white rice husk ash on strength, porosity, conductivity and corrosion resistance of white concrete. Construction and Building Materials 31 (2012) 220-225

[13] Shi C, Wu Y, Riefler C, Wang H. Characteristic and puzzolanic reactivity of glass powders. Cement and Concrete Research 2005; 35:987-93.

[14] Topcu IB, Canbaz M. Properties of concrete containing waste glass. Cement and Concrete Research 2004; 34:267-74

[15] Shayan A. Value-added utilization of waste glass in concrete. Cement and Concrete Research 2004; 34:81-9..

[16] Sandoor Popovics,Analysis of concrete strength Versus Water-Cement Ration Relationship,ACI Material Journal,Vol.87,No.5,September-October 1990,Pp.517-529.

\section{AuThORS}

K.Madhan gopal currently working as an Assistant professor in the Department of Civil Engineering, RGM College of Engineering \& Technology (Autonomous), Nandyal.

Dr.G.Sreenivasulu currently working as an Professor in the Department ofCivilEngineering, RGM College of Engineering \& Technology (Autonomous), Nandyal

Dr.C.Shashidhar currently working as an Professor in the Department of Civil Engineering, JNTUA, Ananthapuramu.

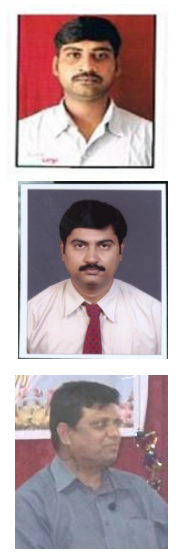

